Wolff, J; (2007) Equality: The recent history of an idea. Journal of Moral Philosophy , 4 (1) 125 136. $10.1177 / 1740468107077389$

\title{
ARTICLE
}

\section{Equality: The Recent History of an Idea ${ }^{1}$}

Jonathan Wolff

\section{Pre-Nozickian Theories of Equality}

Without doubt John Rawls' $A$ Theory of Justice, ${ }^{2}$ is the most important work of political philosophy for many decades, and at its heart is an egalitarian theory of justice. So one would be forgiven for assuming that the discussion of Rawls should be at the centre of the development of contemporary theories of equality. Yet, the position is not quite like that. Rawls's theory is, indeed, taken as a fixed point in the debate; a constant source of reference and often recruited as a precursor or implicit supporter of a theorist's own views, as well as, by others, a source of error or over-simplification. Yet in terms of creating a focal point for discussion of equality it is the work first of Dworkin, ${ }^{3}$ and then increasingly Sen,${ }^{4}$ rather than Rawls, which has created the springboard for the detailed work of others.

Rawls $A$ Theory of Justice is as much a book about how to argue about theories of justice as the presentation of a theory in its own terms. Both projects are carried out in tandem, and at great length and detail with unmatched insight. Yet the salient features of Rawls' view for the contemporary discussion of equality can be stated rather briefly. First there is the question of what, since Cohen has become known as the 'currency' of egalitarian justice. ${ }^{5}$ That is, when we are assessing a state of affairs to see whether it meets the appropriate standard of justice, we need to know what it is about people we should measure. Is it their standard of living; their happiness; their health; their wealth or something else again? Rawls's answer is that government should pay attention to what

\footnotetext{
${ }^{1}$ This paper builds on a presentation given at the University of Sheffield. I thank Fabian Freyenhagen for the suggestion that I should write it up for publication in this journal, and for comments on a draft.

${ }^{2}$ Rawls, John, A Theory of Justice (Oxford: Oxford University Press, 1971).

${ }^{3}$ Dworkin Ronald, "What is equality? Part 1: Equality of welfare", Philosophy \& Public Affairs 1981, 10: 228-240; and Dworkin, Ronald "What is equality? Part 2: Equality of resources", Philosophy \& Public Affairs 1981, 10: 283-345. Both reprinted in R. Dworkin Sovereign Virtue (Cambridge Ma.: Harvard University Press, 2000.)

${ }^{4}$ Sen, Amartya, On Economic Equality. (Oxford: Oxford University Press, 1973); Sen, Amartya, 'Equality of What?' in The Tanner Lectures on Human Values ed. S.M. McMurrin (Cambridge: Cambridge University Press, 1980) 195-220; Sen, Amartya, Choice, Welfare and Measurement. (Oxford: Blackwell, 1982); Sen, Amartya, Inequality Re-examined. (Cambridge Ma.: Harvard University Press, 1992); and Sen, Amartya, On Economic Equality. Expanded edition. (Oxford: Clarendon Press, 1997).

${ }^{5}$ Cohen, G. A., "On the currency of egalitarian justice", Ethics 1989, 99: 906-944.
} 
he calls the 'social primary goods'; the 'all-purpose means' which are valuable whatever conception of the good an individual wishes to pursue. For Rawls these are liberty, opportunity, the powers and prerogatives of office, the social bases of self-respect, income and wealth. Yet the principle most relevant for issues of distributive justice, and hence the topic of equality, the 'difference principle' is a principle for the distribution only of wealth and income. The difference principle states that a just society is one which makes the worst off as well off as possible; i.e. that it maximizes the wealth and income of the least advantaged. It's form - that it allows inequalities if they are in the interests of the worst off - and its content - that it distributes income and wealth - are both highly significant.

To understand the current debate, however, we have to take a step further back than Rawls, to Bernard Williams' paper 'The Idea of Equality'. ${ }^{6}$ This is a deep and subtle paper which explores many tensions and nuances within the idea of equality, and, indeed, develops themes that are constantly being re-discovered or re-invented. Yet its initial importance for the current debate relies on a couple of sentences which provoked a strong reaction from Robert Nozick. Williams sees distribution according to need as a key plank in the theory of equality and writes 'The proper ground of the distribution of health care is health need. This is a necessary truth. ${ }^{7}$ This may seem beyond criticism, yet Nozick replies, that if this is a necessary truth then, it seems, by parity of reasoning so should the following 'The proper ground of the distribution of barbering care is barbering need. 8

Of course Nozick wants us to agree that this is not even a truth, never mind a necessary truth. And if that is right, then Williams example of health care does not express a necessary truth either. In the case of hair care we feel that providers of the services should have an important say in who gets to use them. Nozick's point is that the same ought to be true of health care providers. Why should they be forced to respond to need, rather than the highest bidder, or some other criteria?

Nozick's argument against Williams was one part - perhaps even a small part - of the general assault on egalitarian ideas which took place in Anarchy, State, and Utopia. Yet it is highly significant. Nozick presents Williams' argument as the best argument for equality he has seen - challenging the reader to tell him of a better one - and is

\footnotetext{
${ }^{6}$ Williams, Bernard, 'The Idea of Equality' in Philosophy, Politics and Society 2nd series ed. P. Laslett and W.G. Runciman. (Oxford: Blackwell, 1962).

${ }^{7}$ Williams, 'The Idea of Equality', pp. 121-2.

${ }^{8}$ Nozick, Robert, Anarchy, State, and Utopia (Oxford: Basil Blackwell, 1974), p. 233-4.
} 
apparently refuted in a sentence. This suggests that equality those who have defended equality have done so without good arguments, and immediately puts egalitarians on the defensive. Second, Nozick makes an excellent point that egalitarians have tended to consider individuals as consumers, rather than producers. As Nozick puts it, egalitarians tend to reason as if all of a society's resources exist in a 'big social pot' and all that matters is how the contents of this pot are distributed. Yet much, if not all, of this pot consists of goods that are made, or at least transformed, by human endeavour, or of services composed of the actions of others. This point has fallen out of sight of egalitarian thinking. Yet how can one even discuss the distribution of goods without considering their production, and such things as the motivations and rights of those who do produce these goods?

Now, whether or not this appears to be a fair critique of Williams, many will think it a grossly unfair criticism against Rawls. Rawls does not argue for flat equality, but for the difference principle, which will tolerate inequalities as long as they are in the interests of the worst off. The whole point of this is to allow incentives to make individuals more productive, for the benefit of all. Hence Rawls does not ignore the motivations of producers. However, this is only a half answer. Rawls is clear that he does not believe that the more productive have claims of natural right or desert over their production. Laws and institutions are to be set up so that they are to the greatest benefit to the least advantaged; those who have the least income and wealth. Yet, some may think, this remains a very one-sided view. Why should it be that all that ultimately matters is the wealth and income of the least advantaged?

\section{Dworkin and Equality of Resources}

The difficulty for Rawls in this area was brought out very well indeed by Ronald Dworkin, who, in a pair of long papers at the same time, set out a response to Nozick's libertarian challenges, as well as attempting to refute a range of competing egalitarian theories. ${ }^{9}$

Dworkin can be read as raising two central challenges to Rawls. ${ }^{10}$ The first develops Nozick's objections, and can be put like this: before devoting social resources to improving the position of those with the least income and wealth, should we not, at the

\footnotetext{
${ }^{9}$ Dworkin, 'What is Equality? Part 1: Equality of Welfare'; 'What is Equality Part 2: Equality of Resources'.

${ }^{10}$ See also Kymlicka, Will (2002) Contemporary Political Philosophy: An Introduction, $2^{\text {nd }}$ Edition (Oxford: Oxford University Press), Chapter 3.
} 
very least, first investigate how they came to be in that position? Some may be badly off because they are unable to work, or unable to find work. But others may have chosen to do no work. Are they equally deserving or entitled to benefit from the work of others? Can it be fair to tax the hard-working for the benefit of those who are equally capable of hard work, and equally talented, but choose to laze around instead? The difference principle, however, does not require answers to these questions. Hence, to put Dworkin's first argument in a nutshell, it subsidizes scroungers, or to put it less tendentiously, the deliberately under-productive. In Dworkin's view this is contrary to equality. Equality should, other things being equal, allow those who work hard to reap the rewards, while those who chose to do less should bear the consequences of their choices.

A second objection raises a new difficulty. The index of primary goods, and in particular the focus on income and wealth, ignores the fact that some people have much more expensive needs than others. In particular, people who are severely disabled, or have expensive medical requirements, may have a reasonable income, but this could be wholly inadequate to pay the expenses needed to achieve a reasonable level of wellbeing.

The natural response to the problem of expensive needs, such as those of disabled people, would be to abandon primary goods as a currency of justice, and move to assessment of well-being in terms of some form of welfare, such as happiness or preference satisfaction. However, Dworkin argues that this would be a mistake. First he unleashes a battery of objections against the coherence of a welfare measure essentially the difficulty of determining when two different people are at the same level, which of course is central to any theory of equality. But the argument that is most distinctive and has had the greatest impact, is the problem of expensive tastes. Imagine two people who have the same ordinary tastes, talents and resources, and the same ability to convert resources into welfare, however that is construed. Now one of them Louis - decides that he wants to change his tastes, and manages to develop a taste for pre-phylloxera claret and plovers' eggs, and is consequently unsatisfied with beer and hens' eggs. According to Dworkin, the theory of equality of welfare would require a transfer of resources from the person with ordinary tastes to the person with expensive tastes, in order to equalise their resources. This, he plausibly argues, is deeply counterintuitive. 
The difficulties he identifies in Rawls's theory are addressed by Dworkin in a way which avoids the problem of subsidizing expensive tastes. The key insight is that a notion of responsibility can be incorporated within the theory of equality. It is possible to make people responsible for matters within some domains, but not within others. Dworkin makes a distinctive between one's ambitions -including the realm of the voluntary choices one makes - and endowments, which we can think of as including in-born talents, genetic pre-dispositions, and so on. In brief, Dworkin's theory is that while equality requires government to take steps to compensate for the bad 'brute luck' of being born with poor endowments, or unforeseeable poor luck in other aspects of life, it does not require compensation for poor 'option luck' which typically includes the results of freely made choices. Hence on Dworkin's view there is no reason to subsidise Louis, who has made his own choice to develop expensive tastes. Similarly those who choose not to work, if they are able to, will not be subsidised either, and this, in principle, overcomes the 'problem of responsibility' identified with Rawls' Difference Principle.

This, however, leaves us with the question of how to determine the appropriate level of compensation or subsidy. Here Dworkin makes the brilliant move of appealing to the idea first of insurance, and then of hypothetical insurance. His first observation is that real life insurance converts brute luck into option luck. It may be a matter of pure chance whether lightning strikes my house. But it is not a matter of pure chance if I have declined to take out an easily available insurance policy to protect myself from loss. Dworkin's argument is that if insurance is available against a hazard, and I decide not to take out insurance, then, against a background of equality, there is no case in justice for subsidising the uninsured by taxing others who beforehand were no better off. If it were possible to insure against all brute luck then it appears that Dworkin's theory would simply require an equal distribution of resources and then allow people to make their own choices and run whichever risks they wished.

Life, though, is not so simple. Brute lucks affects us from the moment we are born. Some people are born with low talents, or, as already discussed, disabled: this was one of the problems Dworkin identifies for Rawls. But it is not possible to take out insurance against bad brute luck which has already happened. However, it is possible to imagine what insurance one would take out, hypothetically, behind a veil of ignorance in which you knew the preponderance of, and disadvantage caused by, different types of disability, but did not know whether or not you personally were affected. Knowing this information should allow one to decide whether to insure, and if so at what level. Averaging the 
decisions gives a standard hypothetical premium and payout, and these can be used to model a just tax and transfer scheme. A similar move is available to model appropriate welfare payments for those of low talent.

Dworkin's argument, then, has the merit of squaring up to, and attempting to answer, a number of hard questions. What is the currency of justice? How do we make room for issues of responsibility within egalitarian theory? How do we determine the appropriate level of compensation for people of low earning power or who have disabilities? A coherent systematic picture emerges which provides a response to Nozick, and repairs defects identified in Rawls's position. This explains the central place of his work in the literature.

\section{Basic Income}

Before looking at direct responses to Dworkin, it is worth noting that not everyone accepts that the problem of responsibility is as serious as he supposes. An alternative theory suggests that each person is entitled to a payment from the state whether or not they work, or are willing to work or not. This is the theory of 'unconditional basic income', and it has several possible foundations. Philippe van Parijs ${ }^{11}$ and Andrew Levine, ${ }^{12}$ have defended the view essentially on the grounds of neutrality between conceptions of the good; some prefer to work, some prefer not to, and, to simplify, why should we privilege the conception of the good of one over the other? Arguments are also made that it would have various consequential advantages such as ending discrimination against part-time workers, and requiring work with poor conditions to be paid a decent wage. ${ }^{13}$

In an alternative version defended by Hillel Steiner, all human beings are joint owners of the earth and its resources. To simplify, we can imagine each of us as the owner of one share in 'Earth PLC'. Anyone who wishes to use any of the world's resources must pay a rent to do so, and this rent is returned to the shareholders as a dividend. Accordingly anyone who uses more than a per capita share of the world's resources owes more rent than he or she will get back in dividend; those who use less will get more dividend than they must pay in rent. This, of course, yields a payment for everyone, whether they act responsibly or irresponsibly, although, of course, some will pay more in rent than they

\footnotetext{
${ }^{11}$ Van Parijs, Philippe Real Freedom for All (Oxford: Oxford University Press, 1995).

${ }^{12}$ Levine, Andrew Rethinking Liberal Equality (Ithaca NY.:Cornell University Press, 1998).

${ }^{13}$ Van Parijs, Philippe and Van der Veen, Robert 'A Capitalist Road to Communism' Theory and Society 1986, 15, pp. 635-655.
} 
receive back in dividend. ${ }^{14}$ While I will not here pursue this option further, it is necessary to register it as a live and important line in political philosophy.

\section{Equality of Welfare Revisited}

To return to the main line, recall that Dworkin considers and rejects equality of welfare as a possible response to the problem presented by the fact that disabled people may need more resources than other people to achieve an acceptable standard of living. The rejection is based on the argument from Louis's expensive tastes. Richard Arneson, however, suggests that this argument is confused. ${ }^{15}$ The problem with Louis is that he is has deliberately cultivated expensive tastes. He could have achieved the same level of welfare as other people by remaining content with hen's eggs and beer, but for whatever reason he decided to cultivate expensive tastes. Arneson's response is that we need to understand that there is a distinction not only between theories of resources and theories of welfare, but also what we could call 'outcome' and 'opportunity' theories. It is true, Arneson, accepts, that equality of welfare outcomes would require subsidizing Louis's deliberately cultivated expenses tastes. However, Louis does have equality of opportunity for welfare, but he squanders this by deliberately cultivating expensive tastes. If he was born with expensive tastes then the case for subsidising is more compelling, for he would then lack equality of opportunity for welfare. Hence, Arneson argues, Dworkin has drawn the wrong conclusion from his example. In effect, Arneson suggests, Dworkin has compared equality of welfare outcomes with equality of opportunity for resources. The expensive tastes argument shows that equality of welfare outcomes is unacceptable, but this is a reason for moving to an opportunity conception, not a resources conception.

G.A. Cohen argues in a similar way, although unlike Arneson he claims that an adequate theory of equality must use the currency of 'advantage' which incorporates both welfare and resources, although Cohen admits that he has no account of how the two notions can be combined. ${ }^{16}$ Cohen endorses one of Dworkin's arguments against pure welfarism; that it would have the bizarre consequence that it would require transfers from the very cheerful poor - such as Dickens' Tiny Tim - to the wealthy but miserable, such as Scrooge. But equally, Cohen argues, it would be wrong to follow Dworkin and

\footnotetext{
${ }_{14}^{14}$ Steiner, Hillel, An Essay on Rights. (Oxford: Blackwell, 1994).

${ }^{15}$ Arneson R. "Equality and equal opportunity for welfare", Philosophical Studies 1989, 56: 7793.

${ }^{16}$ Cohen, 'On the Currency of Egalitarian Justice'.
} 
endorse a pure resource based metric in which people were not compensated for pain and suffering, for example.

Dworkin, however, is not persuaded by the criticisms of Arneson and Cohen, arguing that the objection to subsidizing expensive tastes is equally strong even if they are the result of genetic pre-disposition. Whether a person should be subsidised for their expensive tastes depends on whether the average person would, hypothetically, have insured against having that taste. The origin of the taste is, for Dworkin, not relevant. Critics are far from convinced that this is plausible response, and I think it is fair to say that the dispute especially between Dworkin and Cohen remains unsettled. ${ }^{17}$

\section{Equality, Priority and Sufficiency}

A different line of criticism of the theory of equality focuses on the question of whether equality is of value in itself. A traditional argument against equality is that it requires levelling down: that if there is a choice between equality at a lower level and inequality at a higher level, then the theory demands equality, even if it makes literally every individual worse off. Although familiar, few egalitarians took this argument seriously, brushing it aside one way or another, until Rawls presented the difference principle, in which inequalities are tolerated when they are to the advantage of the worst off. This prevents levelling down, of course, which is its aim.

It was, however, unclear whether Rawls' theory should be treated as one of equality or not. On the one hand, theorists such as Nagel treated Rawls as a paradigm example of a theorist of equality, ${ }^{18}$ and critics of equality take Rawls as their target. On the other hand it cannot be denied that Rawls' theory permits inequality, and so some more radical theorists criticised Rawls as a theorist of inequality. ${ }^{19}$ The situation, however, has been clarified by two papers, by Harry Frankfurt $^{20}$ and Derek Parfit, ${ }^{21}$ which generate distinctions between a range of theories of different strength and commitment. First, Frankfurt argues that egalitarians are not, or at least should not, be concerned with

\footnotetext{
${ }^{17}$ See the papers in Burley, Jusitne, (ed) Dworkin and His Critics (Oxford: Basil Blackwell, 2004).

${ }^{18}$ Nagel, Thomas, 'Equality' in his Mortal Questions (Cambridge: Cambridge University Press, 1979).

${ }^{19}$ Daniels, Norman, "Equal Liberty and Unequal Worth of Liberty", in N. Daniels, ed. Reading Rawls. (New York: Basic Books, 1975).

${ }^{20}$ Frankfurt H. G., "Equality as a moral ideal", Ethics 1987, 98: 21-43. (Reprinted in H. G. Frankfurt, The importance of what we care about (Cambridge: Cambridge University Press, 1988)).

${ }^{21}$ Parfit, Derek, 'Equality and Priority', in Ideals of Equality ed. Andrew Mason. (Oxford: Blackwell, 1998). See also Temkin, Larry, Inequality (New York: Oxford University Press, 1993).
} 
equality as such, but with whether individuals are leading sufficiently good lives, where this is to be understood non-comparatively. What matters, argues Frankfurt, is whether people have enough to flourish. Comparisons with others are alienating, and deflect oneself from the value of one's own life. Whatever we think of this further point, it cannot be denied that there is a certain attraction to such a 'sufficiency' view, as distinct from equality.

However, there are further options. Parfit describes a Rawlsian-style view as one of 'priority to the worst off', which again is distinct from equality. Indeed this view comes in various strengths. Rawls' own view is one of absolute priority, where the claims of the worst off must always be given priority. Parfit's view is one of a form of 'weighted priority' in which the claims of the worst off have greater weight than then claims of others, but can, at least in theory, be outweighed. On this view there is such a thing as 'asking too much' even if you are the worst off in society.

The contributions of Frankfurt and Parfit have been immensely valuable, allowing theorists better to understand their own intuitions and theoretical commitments. For example, Arneson has moved from an equality view to one of weighted priority. ${ }^{22}$ We will see further applications of these distinctions shortly.

\section{Sen and Capability Theory}

In parallel to Dworkin, Amartya Sen was also developing an egalitarian response to Rawls. Sen was particularly exercised by Rawls's index of well-being in terms of primary goods, and by the fact that this ignored the plight of disabled people. Sen's suggestion is that evaluation of how well an individual's life is going, from the point of view of whether they should be offered state support, should measure neither the resources someone has, or the welfare they are able to derive, but their 'capability to function'. A functioning is what a person can 'do or be': achieve nourishment, health, a decent life span, selfrespect, and so on. A person's 'capability set' is the alternative sets of functionings they are able to achieve with their resources and opportunities, and a capability, therefore is the freedom to achieve a functioning. ${ }^{23}$

This pluralist view of well-being is often regarded as a more realistic account that any theory of welfare or resources. Although Sen's theory is not set out to respond to

\footnotetext{
${ }^{22}$ Arneson R, "Equality of Opportunity for Welfare Defended and Recanted", Journal of Political Philosophy 1999, 7: 488-97.

${ }^{23}$ Sen, 'Equality of What?'
} 
Nozick's objections one can see, nevertheless, that it contains within it a particular theory of responsibility. If one has the capability to achieve functionings, but neglects to do so, then one is responsible for one's own situation and does not have a claim in justice against others for help. This notion of freedom and responsibility, within a theory of equality, has made the theory attractive to many.

Sen's theory has become extremely important in development economics, influencing policy within organisations such as United Nations, encouraging a move away from income measures of poverty, to 'lack of basic functioning'. ${ }^{24}$ This has been among the contributions which won him the Nobel Prize in Economics in 1998. However, political philosophy has found it harder to incorporate Sen's theory, for two main reasons. First, Sen has always refrained from setting out a definitive list of human functionings. Second, on a pluralist view it is very hard to understand what equality means. Equality seems to require a way of measuring functionings against each other, but the essence of a pluralist view is that this is not, in general, possible. Solving the first problem, as Martha Nussbaum has attempted to do in laying out an account of essential human functionings, ${ }^{25}$ simply brings out the difficulty of the second.

Nevertheless, the contributions of Frankfurt and Parfit have allowed political philosophers to make better use of Sen's approach, in that a 'sufficiency view' of capabilities has appeared a more promising approach (Anderson, 1999, Nussbaum, 2006) in which the goal of social policy is to bring each person to a threshold level of sufficiency in each capability. ${ }^{26}$ There are, however, severe difficulties when resource constraints make this impossible. ${ }^{27}$ The theory will need to be supplemented in some way to deal with priority setting between competing claims, and many of the initial difficulties reassert themselves. However, the position may not be completely hopeless, and it has been argued that it is possible to combine a prioritarian position with a (modified) capability view. ${ }^{28}$

\footnotetext{
${ }^{24}$ United Nations Human Development Report 2005 http://hdr.undp.org/

${ }^{25}$ Nussbaum, Martha, Women and Human Development. (Cambridge: Cambridge University Press, 2000). See also, Alkire, Sabina, Valuing Freedoms (Oxford: Oxford University Press, 2002), Robeyns, Ingrid, "The capability approach in practice", Journal of Political Philosophy, 2006, 17: 351-376.

${ }^{26}$ Anderson Elizabeth, "What is the point of equality?", Ethics 1999, 109: 287-337, Nussbaum, Martha, Frontiers of Justice. (Cambridge: Harvard University Press, 2006).

${ }^{27}$ Arneson, R., "Distributive Justice and Basic Capability Equality: 'Good Enough' is not Good Enough", in Alexander Kaufman, ed., Capabilities Equality: Basic Issues and Problems (London: Routledge, 2005).

${ }^{28}$ Wolff, Jonathan and de-Shalit Avner, Disadvantage (Oxford: Oxford University Press, forthcoming).
} 


\section{Relational Equality and The Critique of Luck Egalitarianism}

Alongside the revival of Sen's approach, we have also seen a set of criticisms levelled against the way in which responsibility is incorporated into the theories of Dworkin, Cohen and Arneson. Together, in a phrase coined by Anderson, those theories are collectively referred to as 'luck egalitarianism' as their goal is to 'neutralise' the effects of luck on individual lives. ${ }^{29}$

Pursuit of this goal, however, appears to have a number of unfortunate effects. For example, it will have to split claimants into those who are responsible for their plight and those who are not, which in some circumstances can be humiliating even for those who are entitled to help, who, for example, might have to argue that they are untalented in order to qualify for state support. ${ }^{30}$ Furthermore, many of the policies strictly entailed by the theory seem deeply inhumane, for example, discriminating between the disabled. Those who are responsible for their own disability, on the luck egalitarian view, should not be entitled to any state help. Anderson suggests that the 'negative aim' of egalitarianism should not be to eliminate the effects of bad luck, but to end oppression, domination and exploitation. An equal society is not one which has eliminated the effects of luck, but that has achieved relations of equality between individuals. Such a view has also been defended in recent writing by Samuel Scheffler.. ${ }^{31}$

This move towards 'relational' or 'social' equality picks up a concern running from a older tradition in thinking of equality, exemplified in the works of such thinkers as R.H. Tawney, ${ }^{32}$ and carried forward by David Miller, ${ }^{33}$ Michael Walzer, ${ }^{34}$ and Richard Norman.$^{35}$. Indeed, this theme is prominent in Bernard Williams' paper, which, we saw above, received such savage, and perhaps distracting, criticism from Nozick. ${ }^{36}$ The central idea is that a society of equals has to create conditions of mutual respect, and self-respect and thereby overcome hierarchical divisions. This type of view has strong

\footnotetext{
${ }^{29}$ Anderson, "What is the point of equality?".

${ }^{30}$ Wolff, Jonathan, "Fairness, Respect and the Egalitarian Ethos", Philosophy and Public Affairs 1998, 27:. 97-122; Anderson, "What is the Point of Equality?".

${ }^{31}$ Scheffler, Samuel, "What Is Egalitarianism?" Philosophy and Public Affairs 2003, 31: 5-39.

32 Tawney, R.H., Equality. (London: George Allen and Unwin, 1931).

${ }^{33}$ Miller, David, Principles of Social Justice (Cambridge Ma.: Harvard University Press, 1999).

${ }^{34}$ Walzer, Michael (1983) Spheres of Justice. (Oxford: Blackwell, 1983).

${ }^{35}$ Norman, Richard, 'The Social Basis of Equality', in A. Mason (ed) Ideals of Equality (Oxford: Basil Blackwell, 1998).

${ }^{36}$ Williams, "The Idea of Equality", and Nozick, Anarchy, State, and Utopia.
} 
affinities with the work of the 'difference' theorist Iris Marion Young, ${ }^{37}$ and 'recognition' theorist Nancy Fraser. ${ }^{38}$ There are numerous variation on this theme, but the basic idea is an equal society is one that has the right quality of relations between individuals, rather than one which distributes the 'currency' of justice, the right way.

Even though there appears to be increasing sympathy for the idea that social equality is an indispensable part of an equal society, it is also noted that distributive elements cannot be ignored either. ${ }^{39}$ One major current research programme is to try to work out how distributional and social understandings of equality can be combined in a single view.

\section{Contemporary Developments}

Although there is rather little published on these themes so far, there is increasing attention, evidenced through conferences on the topics, in two related topics. One starts from the observation that much recent work in political philosophy is based on 'ideal theory' or 'full compliance'. That is, its aim is to set out a theory for the just society, assuming that all citizens will follow the rules. However, there is a lurking question about the application of such theories to the real world. It may be impossible to implement a theory for many reasons; that it makes unreasonable demands of human beings; that it is not fully coherent; that there is no political will; that there is no route from where we are to where we would be, and so on. For this reason some theorists are beginning to think that greater attention to issues of 'non-ideal' theory and 'the real world' is needed, following the thought that political philosophy must start from where we are.

This programme is really seamless with another: social justice in practice, which tries to use philosophical theory to consider real social policy issues, and, in turn, modify the theory in the light of such issues. If, for example, a theory of equality suggests ways of dealing with inequality which conflict with existing progressive and enlightened social policies, it seems that, at the least, we should consider whether we have the right theory, and be prepared to revise the theory so that it can not only fit in with the best social policies, but also help determine priorities in hard cases. ${ }^{40}$

\footnotetext{
${ }^{37}$ Young, Iris Marion, Justice and the Politics of Difference (Princeton: Princeton University Press, 1990).

${ }^{38}$ Fraser, Nancy and Honneth Axel, Recognition or Redistribution? (London: Verso, 1998).

${ }^{39}$ Phillips, Anne (1999) Which Equalities Matter? (Oxford: Polity).

${ }^{40}$ See, for example, Barry, Brian Why Social Justice Matters (Oxford: Polity, 2005); Tremain, Shelley, 'Dworkin on Disablement and Resources', Canadian Journal of Law and Jurisprudence 1996, 9: 343-59; Wolff, Jonathan (2002) 'Addressing Disadvantage and the Human Good',
} 


\title{
Conclusion
}

Equality is a vibrant area of interest. Much of the work conducted over the last two decades has been in response to an agenda set by Robert Nozick's powerful criticisms of equality, and especially on the claimed neglect of issues of personal responsibility within egalitarian theory. However, in attempting to respond to Nozick it is arguable that these concerns have distorted the theory, paying too much attention to issues of individual responsibility, choice and fairness, and neglecting the traditional egalitarian concerns of respect for individuality social division, oppression and domination, and, indeed, how to bring about improvements to the world we actually live in. There remains a great deal to be done.

\author{
Jonathan Wolff \\ Department of Philosophy \\ University College London \\ j.wolff@ucl.ac.uk
}

Journal of Applied Philosophy, 2002, 19: 207-218; and Wolff and de-Shalit, Disadvantage. 